\title{
SKIN MANIFESTATIONS IN HIV/AIDS PATIENTS - OUR EXPERIENCE
}

\author{
Djurovic Milena, ${ }^{1}$ Andric Bogdanka, ${ }^{2}$ Djurovic Milica, ${ }^{1}$ Bojic Milos $^{3}$ \\ ${ }^{1}$ Clinic of Dermatology and Venereology, Clinical Center of Montenegro, Faculty of Medicine, \\ University of Montenegro, Podgorica, Montenegro \\ ${ }^{2}$ Clinic of Infectious Diseases, Clinical Center of Montenegro, Faculty of Medicine, \\ University of Montenegro, Podgorica, Montenegro \\ ${ }^{3}$ Clinic of Plastic Surgery, Clinical Center of Montenegro, Podgorica, Montenegro
}

Primljen/Received 19. 02. 2021. god.

Abstract: Objective: HIV/AIDS represents a significant public health issue since the number of cases is continuously on the rise. Even though contemporary medicine is rapidly developing, there is currently no effective cure for HIV. Mucocutaneous manifestations often represent the first recognized clinical manifestation. This study was carried out to note different presentations of HIV/AIDS on the skin.

Material and Methods: The study included 150 patients who were hospitalized and have been confirmed as HIV positive either before the hospitalization or during the hospitalization.

Results: Out of 150 patients, 50 of them had mucocutaneous presentations. Frequently, mucocutaneous lesions are the first manifestation of HIV/AIDS and a pointer toward setting up HIV/AIDS diagnosis. Moreover, the same patient was admitted more than once, because of a variety of skin manifestations.

Conclusion: It was recognized that the greater the destruction of the immune system is, the more severe forms of mucocutaneous diseases occur. It is considered that cutaneous manifestations are rarely considered life-threatening in people living with HIV, but they can undoubtedly impair their quality of life.

Keywords: Mucocutaneous lesions, HIV/AIDS, immune system activation, HIV pandemic, ART.

\section{INTRODUCTION}

HIV / AIDS are two stages of a deadly infectious disease of viral etiology. The causative agent, HIV was discovered in 1983. It belongs to the family of non-oncogenic retroviruses, subfamilies of lentiviruses. Studies have shown the inhomogeneity of HIV and the majority belong to the HIV-1 variant. The HIV-2 variant is present only in West Africa and represents a less virulent form than HIV-1 (In HIV-1 and HIV-2, only about
Prihvaćen/Accepted 10. 04. 2021. god.

$40 \%$ of the sequences are identical.) $(1,2,3)$. The basic effect of HIV infection is the progressive destruction of the immune system, up to the terminal phase of AIDS, which is characterized by pronounced suppression of the immune system and the development of fatal coinfections, opportunistic infections, and tumors (4). After entering the body, HIV binds to receptors on the surface of CD4 lymphocytes and other cells: Langerhans cells, cells of the monocyte-macrophage line, which serve as reservoirs and carriers of the virus $(5,6,7)$.

In order to enter the cell, HIV requires a cofactor: CCR-5 (for tropic macrophages) and CXCR-4 (for lymphotropic variants of HIV). The first step of HIV entry into the cell is the fusion of proteins (GP 120) with CD4.

A strong Th1 response can keep the virus under control for a long time. (asymptomatic period lasts about 10 years). However, in most infected people, this cellular response does not last that long. The production of specific antibodies (Th2 response) is activated, which are significantly less effective. The number of viruses gradually increases and progressively destroys CD4 cells. Cells that are not destroyed are damaged, which also reduces the body's defense possibilities. The virus itself is capable of destroying CD4 cells, by triggering the mechanisms of programmed death (apoptosis). By destroying key defense cells, a complete breakdown of the immune system and the manifestation of AIDS occurs. It attacks and kills the regulatory $\mathrm{T}$ cells needed for the immune response (when there are no CD4 cells, the ability to make CD8 cells is lost) (8).

\section{AIM}

Skin changes are common in people living with HIV and may be the first manifestation of HIV. It is reported that up to $90 \%$ of people living with HIV 
around the world have or had skin changes (5). It is considered that cutaneous manifestations are rarely considered life-threatening in people living with HIV, but they can undoubtedly impair their quality of life. Although the use of HAART prolongs life expectancy, many people living with HIV suffer from facial lipoatrophy as a result of a response to therapy and many other dermatological manifestations, such as psoriasis-like syndrome. In addition to cosmetic disfigurement, in eosinophilic folliculitis, intense pruritus can seriously impair the quality of life of the infected $(1,2,3)$.

Most commonly, there is no difference between the treatment of skin manifestations in HIV/AIDS positive and negative patients. However, systemic administration of high-dose steroids in longer runs should be used with caution due to its immunosuppressive effects.

According to numerous studies, and generally accepted rules, the spectrum of skin manifestations depends on: the immune stage of the disease, the number of CD4 cells, the simultaneous use of HAART, and the pattern of endemic infections. These changes are also influenced by the geographical distribution of various infectious agents. (e.g. penicilliosis is more frequent in Southeast Asia and Hong Kong than in the Western world). In advanced stages of HIV infection, skin changes often have an unusual appearance, which makes setting up the diagnosis difficult.

During the study of skin manifestations, some authors came to the conclusion that the introduction of HAART, due to the improvement of host immunity, changed the spectrum of skin manifestations in HIV/ AIDS people. It is reported to reduce the incidence of Kaposi's sarcoma, eosinophilic folliculitis, dermatophyte infections, molluscum contagiosum, and others, and increase the number of HIV-positive people with herpes viruses: HZ, HSV, CMV, EBV, and some other agents with skin affinity (1).

Due to all previously mentioned, it is important to keep in mind the importance of skin manifestations. Not rarely, skin manifestations could be the pointer for revealing HIV status. It seems that a large number of physicians do not have that in mind. Skin conditions are usually not life-threatening, but it is important not to neglect them. Instead, health professionals should observe them and try to find the eventual underlying condition that triggered skin changes.

\section{MATERIAL AND METHODS}

Comprising the period from 1995 to 2015, we observed 150 patients diagnosed with HIV/AIDS to identify the type, frequency, and severity of skin

Table 1. The frequency of dermatologic manifestations in our HIV/AIDS patients

\begin{tabular}{|c|l|r|c|}
\hline No. & \multicolumn{1}{|c|}{ Dermatological manifestation } & $\begin{array}{c}\text { Number of patients (total } \\
\text { number } \\
\text { of patients }=50)^{*}\end{array}$ & $\begin{array}{c}\text { Percentage of patients } \\
\text { that had certain skin } \\
\text { manifestation }\end{array}$ \\
\hline 1. & Skin changes due to primary HIV infection & 15 & $30 \%$ \\
\hline 2. & Hairy leukoplakia & 2 & $4 \%$ \\
\hline 3. & Herpes simplex (HSV-1 and HSV-2) & 9 & $18 \%$ \\
\hline 4. & Disseminated bullous herpes zoster & 3 & $6 \%$ \\
\hline 5. & Cutaneous CMV infection & 2 & $4 \%$ \\
\hline 6. & Molluscum contagiosum & 7 & $14 \%$ \\
\hline 7. & HPV condylomata & 3 & $6 \%$ \\
\hline 8. & Oral candidiasis & 23 & $46 \%$ \\
\hline 9. & Cutaneous candidiasis and Onychomycosis & 2 & $4 \%$ \\
\hline 10. & Hystoplasmososcutanea & 1 & $2 \%$ \\
\hline 11. & Scabies & 5 & $10 \%$ \\
\hline 12. & Angiomatosis bacillaris & 1 & $2 \%$ \\
\hline 13. & Dermatitis seborrhoea & 11 & $22 \%$ \\
\hline 14. & Kaposi sarcoma & 2 & $4 \%$ \\
\hline 15. & Non-Hodgkins lymphoma cutis & 1 & $2 \%$ \\
\hline
\end{tabular}

*Single patients had more than one mucocutaneous manifestation 
manifestations. Among this group, we registered skin changes in 50 patients. After a deep analysis of skin changes, our experience has shown that the most commonly registered skin changes in the study group were due to herpes virus infections (HSV, VZV, EBV, and $\mathrm{CMV}$ ) and fungal infections. Less common were parasitic, bacterial infections, and tumors.

The diagnostic examinations were performed at the Infectious and Dermatology Clinic of the Clinical Center of Montenegro, among the patients who were admitted due to the worsening of clinical signs. Among the respondents, the youngest was 18 years old, and $85 \%$ were on ART. Epidemiological data, clinical and laboratory examinations were performed during the study. Routine laboratory examinations included Complete Blood Count, CD4 Count, and Liver Functional Tests. In cases where it was needed tissue samples for biopsy were obtained, chest X-ray, microbiological tests, serological tests, etc. All the tests were used to evaluate the overall being of patients. Diagnostic tests (ELISA, Western Blot) were also used for etiological confirmation of HIV/AIDS.

\section{RESULTS}

The first case of HIV infection in Montenegro was registered in 1986 (sailor from the seaside). Data from 50 patients were included in our observation. The most common dermatologic manifestations were skin changes due to primary HIV infection, represented by exanthems. According to the epidemiological data, the most common way of transmission was the sexual route of transmission. Not all the patients had just one skin manifestation. Thus, some of them looked for help because of skin issues more than once due to different skin diseases. Out of 50 patients, 15 had just one skin disease or $30 \%$ of patients had one skin manifestation. 31 patients $(62 \%)$ were admitted twice, and just 3 patients $(8 \%)$ had three different skin manifestations. Among the respondents, the youngest was 18 years old, and $85 \%$ were on HART/ART therapy. In Table 1 we presented dermatologic manifestations of HIV/AIDS according to our experience.

\section{DISCUSSION}

\section{Primary HIV infection (Acute Seroconversion Syndrome)}

Primary HIV infection (Acute Seroconversion Syndrome) is similar to EBV infection. Fever, laryngitis, cervical adenopathy are often accompanied by polymorphic exanthem (in $70 \%$ of cases) (9). It can be manifested as erythematous, maculopapular rash, often with a tendency to confluent. The eruption is distributed throughout the trunk, sometimes on the palms and soles (similar to secondary syphilis). During this phase of infection, oral and genital erosions were also found. Histologically, nonspecific mononuclear infiltrates are found in the upper dermis (10).

\section{Oral hairy leukoplakia}

It manifests with the formation of thick, whitish adherent deposits, which cannot be removed. The lesions are located on the buccal mucosa, the bottom of the oral cavity, or on the tongue. The etiological cause of hairy leukoplakia is considered to be Epstein Bar Virus (EBV), although other infectious agents have been found. Leukoplakia may appear as one of the first symptoms of HIV infection (11).

\section{Herpes simplex viral (HSV) infections (HSV-1 and $\mathrm{HSV}-2$ )}

Symptomatic and asymptomatic reactivated HSV infections are common even nowadays among the HIV population and can be the cause of significant morbidity and even lethality in the HIV/AIDS population in conditions of severe immunodeficiency (12).

\section{Disseminated bullous herpes zoster}

The clinical occurrence of HZ among HIV-positive individuals is usually no different from that in individuals without HIV infection. Nevertheless, lesions affecting more dermatomes are more common in advanced stages. Atypical manifestations, like necrotic ulcers or hyperkeratotic ulcerated nodules, are reported to be more common when the immune system is more destroyed (13).

\section{Cutaneous manifestations in people living with HIV, caused by cytomegalovirus (CMV)}

Systemic CMV infection is common in people living with HIV, while mucosal and skin lesions are rare. If mucocutaneous lesions occur, oral or perianal ulcers are the most frequent clinical image. Papulovesicular eruptions, purpura, nodules, and verrucous lesions on the skin have also been registered (14).

\section{Molluscum contagiosum (MC)}

The causative agent is the Poxvirus, which selectively infects human epidermal cells. The disease has a benign course in immunocompetent, but severe and long-lasting in immunodeficient. In the advanced stages of immune system destruction, giant and verrucous forms of MC may occur. MC in HIV/AIDS patients 
is persistent, hard to cure and treat, and tends to be chronic (15).

\section{Cutaneous manifestations of human papillomavirus infection in people living with HIV/AIDS}

Both HIV and HPV viruses can survive in the body for years in a latent state without manifest symptoms of the disease. In people who have both HPV and HIV infection, both viruses can make a person more susceptible to other diseases or complications. The extent of the disease depends on the state of the immune system and numerous types of HPV, of which some are at low-risk types for the development of malignancies and some are at high risk (16).

\section{Fungal Infections}

1. Oral candidiasis

Mucocutaneous candidiasis is usually caused by Candida albicans. It is one of the most common mucocutaneous findings in HIV disease. It manifests as oral thrush, cutaneous cheilitis, balanitis, intertrigo, paronychia, and vaginal thrush. Oropharyngeal candidiasis may present as an erythematous or hyperplastic type (17).

\section{Dermatophytosis and onychomycosis}

The clinical image of these fungal infections is generally similar to those of non-HIV-infected individuals. Tinea unguium is often associated with tinea pedis. "Proximal white subungual onychomycosis" is a regularly less common presentation, but more specific for HIV infection. The administration of systemic therapy is usually needed, as topical therapy is not effective (18).

\section{Scabies}

In people with HIV/AIDS who suffer from scabies, skin changes are generally similar to those without HIV infection but are usually more extensive and severe (exaggerated).In one case of advanced HIV/ AIDS infection, manifestations of scabies were similar to Norwegian scabies. Norwegian scabies occurs mainly in people with a significantly weakened immune system. The treatment of the disease is very difficult, and the contagiousness is great. Thick crusts appear on the skin which often cover large areas of the body. The changes were not accompanied by itching (19).

\section{Seborrhoeic dermatitis}

Seborrhoeic dermatitis is a common skin condition that mainly affects the hairy part of the head. It is manifested by scaly changes, reddish skin, and stubborn dandruff. The tendency to recur is also one of the common features of seborrhoeic dermatitis. ART decreases the prevalence of seborrhoeic dermatitis and those who are under ART treatment may experience milder and less severe clinical presentation (20).

\section{Bacillary angiomatosis}

Bacillary angiomatosis is a systemic infectious disease that affects both the skin and internal organs. It is characterized by the development of angiomatous lesions, which can be clinically reminiscent of Kaposi's sarcoma (21).

\section{Kaposi’s sarcoma}

Kaposi's sarcoma (KS) is a soft tissue malignant tumor. Skin lesions are usually purple. They may occur in a limited area or be disseminated. Tumor deterioration may occur very rapidly or gradually. Although the etiology of these changes is not yet fully known, human herpesvirus 8 is found in lesions. Four clinical forms of this tumor have been described: classic, endemic, immunosuppressive - therapeutic, and epidemic (HIV related). The classic form usually occurs in older males, progresses slowly, and is usually located on the skin of the lower extremities. Endemic form occurs in young adult males in Africa and may be more aggressive. KS associated with immunosuppressive therapy usually occurs in humans after organ transplantation and mainly affects the skin. The KS epidemic form occurs in people living with AIDS and represents the second most common tumor in HIV/ AIDS people (22).

Dermatological manifestations could appear in all stages of HIV/AIDS, regardless of the severity of infection/disease. They appear as skin infections or inflammations, immune and malignant diseases. After the introduction of antiretroviral therapy, some dermatological manifestations became rare, but new diseases appeared, such as immune restoration diseases, then lipodystrophic skin disorders, etc (6).

Manifestations such as MC, oral leukoplakia, oral candidiasis, chronic ulcerative HS, and KS are strongly associated with the progression of HIV immunodeficiency. In the last decade, highly active ART has significantly changed the course of HIV infection by empowering the immune system and improving the clinical signs of dermatological manifestations (7).

Symptoms of skin disorders, which are more frequent among HIV-positive patients compared to HIV-negative patients, are also characterized by their complexity, atypia, and therapeutic resistance in any case affecting the quality of life of HIV-positive patients. 
Of the non-infectious skin disorders in HIV-positive patients, lesions represented as pruritic papular eruption were the most frequent cutaneous manifestation $(1,2)$.

Studies conducted in Pakistan to determine the pattern and prevalence of mucocutaneous lesions in HIV patients revealed that fungal infections prevailed, starting with the most frequent oral candidiasis and onychomycosis. Herpes zoster and HPV infections had the highest prevalence among HIV-accompanying viral diseases. Bacterial infections in these patients were mainly of the folliculitis type. Among other clinical manifestations, photosensitivity, scabies, and hyperpigmentation were less common (23).

A study conducted in Iran showed that $32 \%$ of HIV-infected patients had a CD4 cell count lower than 300 cells $/ \mathrm{ml}$. Participants with lower CD4 had more frequent symptoms and more severe clinical presentation. In this study, CD4 cell counts were found to have a positive and significant correlation with skin diseases and that these skin disorders can help in faster HIV diagnosis. Information was accepted with reservations, given the differences in the results of examinations by other authors, which do not find a relationship between the number of CD4 cells $(\mathrm{P}=0.274)$ and the severity of clinical manifestations, with the explanation that many skin disorders can occur in HIV patients with normal CD4 cell counts. In our series of Bartonella henselae infection studies, extensive disseminated changes (on the skin, liver) were found in a patient with a normal CD4 cell count, without signs of immunodeficiency of any etiology (24).

\section{CONCLUSION}

Since the discovery up to this day, HIV/AIDS issue remains the main challenge in the field of medical sciences, and the subject of intensive scientific research, in particular, the immuno-pathogenetic characteristics of the infection, effective prevention, and treatment.
Mucocutaneous manifestations of HIV/AIDS were first registered in patients in the early 1980s. A handful of researches have shown that no skin disease is caused specifically by HIV/AIDS. However, diseases such asKS and eosinophilic folliculitis strongly suggest the HIV etiology of the changes. In HIV/AIDS, skin diseases usually present with more severe clinical presentations, tending to become chronic, recurrent, and resistant to treatment. At the end of $2019,81 \%$ of people living with HIV knew their status. It is estimated that $67 \%$ of people received ART and 59\% achieved HIV control without the risk of infecting others. At the end of 2019, 25.4 million people started ART. Between 2000 and 2019, new HIV infections fell by $39 \%$, HIV-related deaths fell by $51 \%$, and 15.3 million lives were saved due to ART. These results were achieved due to the tough efforts of national and international HIV programs and the strong actions of major health institutions and civil societies
Abbreviations
AIDS - acquired immunodeficiency syndrome
HIV - human immunodeficiency virus
CCR - C-C chemokine receptor type 5
CXCR - C-X-C chemokine receptor type 4
EBV - Epstein Bar Virus
ART - antiretroviral therapy
HAART - highly active antiretroviral therapy
HZ - herpes zoster
VZV - Varicella zoster virus
HSV — herpes simplex virus
CMV - Cytomegalovirus
HPV - Human papillomavirus
KS - Kaposi's sarcoma

Conflict of Interests: The authors declare that there are no conflicts of interest related to this article.

Funding: None

\title{
Licensing
}

This work is licensed under a Creative Commons Attribution 4.0 International (CC BY 4.0) License.

\section{Sažetak}

\section{DERMATOLOŠKE MANIFESTACIJE KOD HIV/AIDS PACIJENATA- NAŠE ISKUSTVO}

\author{
Đurović Milena, ${ }^{1}$ Andrić Bogdanka, ${ }^{2}$ Đurović Milica, ${ }^{1}$ Bojić Milos ${ }^{3}$ \\ ${ }^{1}$ Clinic of Dermatology and Venereology, Clinical Center of Montenegro, Faculty of Medicine, \\ University of Montenegro, Podgorica, Montenegro \\ ${ }^{2}$ Clinic of Infectious Diseases, Clinical Center of Montenegro, Faculty of Medicine,
}


Cilj: HIV/AIDS predstavlja značajno javno-zdravstveno pitanje, jer je broj zaraženih/obolelih u stalnom porastu. Iako se savremena medicina ubrzano razvija, trenutno ne postoji efikasan lek za HIV. Kutane manifestacije često predstavljaju prvu prepoznatu kliničku manifestaciju HIV/AIDSa, a neretko se kožne manifestaciju zanemaruju. Ova studija je sprovedena kako bi se zabeležile različite prezentacije HIV/AIDS-a na koži.

Materijal i metode: Studija je obuhvatila 150 stacionarnih bolesnika koji su bili hospitalizovani i kojima je potvrđeno da su HIV pozitivni ili pre hospitalizacije ili tokom hospitalizacije.

Rezultati: Od 150 pacijenata, 50 pacijenata su imali kožne manifestacije. Neretko su kožne i slu-

\section{REFERENCES}

1. Richman DD,Bozzette SA. The impact of the syncytium - inducinephenothype of human immunodeficiency virus on disease progression. J Infect Dis. 1994; 169(5): 968-74. doi: 10.1093/infdis/169.5.968.

2. O’Donovan D, Ariyoshi K, Milligan P, Ota M, Yamuah L, Sarge-Njie R, et al. Maternal plasma viral RNA levels determine marked differences in mother-to-child transmission rates of HIV-1 and HIV-2 in The Gambia. MRC/Gambia Government/University College London Medical School working group on mother-child transmission of HIV. AIDS. 2000; 14(4): 441-8. doi: 10.1097/00002030-200003100-00019.

3. Dean M, Carrington M, Winkler C, Huttley GA, Smith MW, Allikmets R, et al. Genetic restriction of HIV-1 infection and progression to AIDS by a deletion allele of the CKR5 structural gene. Hemophilia Growth and Development Study, Multicenter AIDS Cohort Study, Multicenter Hemophilia Cohort Study, San Francisco City Cohort, ALIVE Study. Science. 1996; 273(5283). 1856-62. doi: 10.1126/science.273.5283.1856.

4. Ndour M, Sow PS, Coll-Seck AM, Badaine S, Ndour CT, Diakhate N et al. AIDS caused by HIV1 and HIV2 infection: are there clinical differences? Results of AIDS surveillance 1986-97 at Fann Hospital in Dakar, Senegal. Trop Med Int Health. 2000; 5(10): 687-91. doi: 10.1046/j.13653156.2000.00627.x.

5. Sharp PM, Hahn BH. Origins of HIV and the AIDS Pandemic. Cold Spring Harbor Perspect Med. 2011; 1(1): a006841. doi: 10.1101/cshperspect.a006841.

6. Centers for Disease Control and Prevention. (2014) HIV/AIDS: Statistics Overview. Accessed at www.cdc.gov/hiv/ statistics/basics/index.html on July 21.

7. Joint United Nations Programme on HIV/AIDS (UNAIDS); World Health Organization. AIDS epidemic update: December 2009. Geneva: Joint United Nations Programme on HIV/AIDS (UNAIDS); 2009.

8. Matsiyeuskaya VN, Tsyrkunov MV. Activation of blood T-cells in HIV/HCV co-infected patients. Sanamed. 2013; 8 (1): 11-8.

9. Moir S, Chun TW, Fauci AS. Pathogenic, echanisms of HIV disease. Annu Rev Pathol. 2011; 6: 223-48. doi: 10.1146/ annurev-pathol-011110-130254. zokožne lezije prva manifestacija HIV/AIDS-a i vodič ka postavljanju dijagnoze HIV/AIDSa. Štaviše, u našoj studiji i isti pacijent je primljen više puta zbog različitih kožnih manifestacija.

Zaključak: Prepoznato je da što je veća destrukcija imunološkog sistema, to se javljaju teži oblici mukokutanih bolesti. Smatra se da se kožne manifestacije retko smatraju opasnim po život ljudi koji žive sa HIV-om, ali nesumnjivo mogu narušiti njihov kvalitet života.

Ključne reči: mukokutane lezije, HIV/AIDS, aktivacija imunog sistema, HIV pandemija, ART.

10. Sullivan PS, Fideli U, Wall KM, Chomba E, Vwalika $\mathrm{C}$, Kilembe $\mathrm{W}$ et al. Prevalence of seroconversion symptoms and relationship to set-point viral load: findings from a subtype C epidemic, 1995-2009. AIDS. 2012; 26(2): 175-84. doi: 10.1097/QAD.0b013e32834ed8c8.

11. Tappuni AR. The global changing pattern of the oral manifestations of HIV. Oral Dis. 2020; 26( Suppl 1): 22-7. doi: 10.1111/odi.13469.

12. Munawwar A, Grupta S, Sharma SK, Singh S. Seroprevalence of HSV-1 and 2 in HIV-infected males with and without GUD: Study from a tertiary care setting of India. J Lab Physicians. 2018; 10(3): 326-31. doi: 10.4103/JLP.JLP_7_18.

13. Kakitha R, Shanmugam S. Bullous pemphigoid-like presentation of disseminated Herpes Zoster: a case report. Indian J Dermatol. 2020; 65(3): 234-5. doi: 10.4103/ijd.IJD_337_18.

14. Perello R, Vergara A, Monclus E, Jimenez S, Montero $\mathrm{M}$, Saubi $\mathrm{N}$ et al. Cytomegalovirus infection in HIV-infected patients in the era of combination antiretroviral therapy. BMC Infectious Diseases. 2019; 19(1): 1030. doi: 10.1186/s12879019-4643-6.

15. Gaurkar SP, Pund PB, Dindore PR, Bhoi UY. Extensive molluscum contagiosum causing obstruction of vision in HIV-positive women. Indian Dermatol Online J. 2016; 7(3): 190-1. doi: 10.4103/2229-5178.182360.

16, Clifford GM, Tully S, Franceschi S. Carcinogenicity of Human Papilloma virus (HPV) types in HIV-positive women: a meta-analysis from HPV infection to cervical cancer. Clin Infect Dis. 2017; 64(9): 1228-35. doi: 10.1093/cid/cix135.

17. Patil S, Majumdar B, Sarode SC, Sarode GS, Awan KH. Oropharyngeal candidosis in HIV-infected patients-an update. Front Microbiol. 2018; 9: 980. doi: 10.3389/fmicb.2018.00980.

18. Ali SY, Gajjala SR, Raj A. Study of the prevalence of dermatophytes among human immunodeficiency virus/AIDS patients in Shadan Institute of Medical Sciences and Teaching Hospital and Research Centre, Hyderabad, Telangana, India. Indian J Sex Transm Dis AIDS. 2018; 39(2): 98-101. doi: 10.4103/ijstd.IJSTD_103_16.

19. Tirado-Sánchez A, Bonifaz A, Montes de Oca-Sánchez G, Araiza-Santibañez J, Ponce-Olivera RM. Escabiosis costrosa en pacientes con infección por VIH/SIDA. Reporte de 15 casos 
[Crusted scabies in HIV/AIDS infected patients. Report of 15 cases]. Rev Med Inst Mex Seguro Soc. 2016; 54(3): 397-400.

20. Forrestel AK, Kovarik CL, Mosam A, Gupta D, Maurer TA, Micheletti RG. Diffuse HIV-associated seborrheic dermatitis - a case series. Int J STD AIDS. 2016; 27(14): 1342-5. doi: 10.1177/0956462416641816.

21. Balaban M, Ioana Nedelcu R, Balmes G, Adela Todorovic T, Brinzea A, Nichita Let al. Bacillary angiomatosis triggered by severe trauma in a healthy Caucasian patient: A case report. Exp Ther Med. 2020; 20(1): 56-60. doi: 10.3892/ etm.2019.8260.

\section{Correspondence to/Autor za korespondenciju}

Milena Djurovic

Deparment of Dermatovenerology, Clinical Center of Montenegro, Podgorica, Montenegro

email: milena.djurovic@kccg.me

phone: 0038269544000
22. Curtiss P, Strazzulla LC, Friedman-Kien AE. An Update on Kaposi's Sarcoma: Epidemiology, Pathogenesis, and Treatment. Dermatol Ther (Heidelb). 2016; 6(4): 465-70. doi: 10.1007/s13555-016-0152-3.

23. Azfar NA, Khan AR, Zia MA, Humayun A, Malik LM, Jahangir M. Frequency of mucocutaneous manifestations in HIV positive Pakistani patients. J Pak Assoc Dermatol 2011; 21: 149-53.

24. Foroughi M, Koochak HE, Roosta N, Paydary K, Khatami A, Shahriari S et al. Prevalence of dermatologic manifestations among people living with HIV/AIDS in Imam Khomeini Hospital in Tehran, Iran. Journal of AIDS and HIV Research. 2012; 4(2): 56-9. 